\title{
Главная улица Тверского кремля в XVI столетии (опыт реконструкции)
}

\author{
А.М.Салимов, НИИТИАГ, Москва
}

Реконструкция планировочной структуры и характера застройки Тверского кремля на период развитого средневековья в силу чрезвычайно ограниченного числа письменных и тем более иллюстративных источников представляется на сегодняшний день весьма сложным делом. Решению этой проблемы отчасти способствуют результаты архитектурноархеологических и археологических раскопок, но даже они вкупе с другим документальным материалом не снимают многочисленных трудностей, возникающих на пути исследователя, пытающегося выполнить подобную реконструкцию. Тем не менее потребность в такой визуализации существует особенно сейчас, когда идёт создание новой экспозиции в Тверском государственном краеведческом музее. Период же, который выбран в данном случае для реконструкции XVI столетие - представляется наиболее значительным в развитии градостроительной структуры центральной части Тверского кремля и его основной магистрали, увязывавшей главный въезд в крепость (Владимирскую башню) и его Тьмацкие ворота.

B рамках XVI века пик развития досмутной Твери пришёлся, скорее всего, на середину - вторую половину этого столетия, хотя начало этому процессу было, вероятно, положено ещё на рубеже XV-XVI веков. Во времена Василия III (1505-1533) обустройство кремлёвской территории происходило, по всей видимости, более энергично, но пожар 1537 года, уничтоживший значительную часть кремля, мог привести к кардинальным переменам в его застройке. В итоге при подготовке реконструкции автор ориентировался на период, нижней границей которого служит конец 1530-х годов, а верхней - рубеж 60-x - 70-х годов XVI века, поскольку в декабре 1569 года Тверь была разорена опричниками Ивана Грозного*).

Ключевые слова: Тверской кремль, застройка главной улицы, соборный комплекс, Княжий и Владычный дворы.

The Main Street of Tver Kremlin in the 16th Century (an Attempt of Reconstruction)

A.M.Salimov, NIITIAG, Moscow

Reconstruction of Tver kremlin planning structure and the character of its building for the period of developed Middle

*) Работа выполнена по Программе фундаментальных научных исследований Российской академии архитектуры и строительных наук (РАAСН) и при финансовой поддержке РФФИ в рамках научного проекта № 19-012-00025.
Ages now seems to be a very complicated work because of rather limited number of writing and especially graphical sources. The results of architectural-archaeological and archaeological excavations help to solve this problem partly, but even they together with other documental materials leave a lot of difficulties which appear on a researcher's way who tries to make such a reconstruction. Nevertheless, there is a need of this visualization, especially now, when a new exposition is creating in Tver State Museum of Regional Studies. The period chosen in this case for reconstruction - the 16th century - seems to be the most significant for the development of town-planning structure of the central part of Tver kremlin and its main street connected the main entrance in the fortress (Vladimirskaya Tower) and its Tmatskie Gate.

In the 16th century a peak of pre-Time of Trouble Tver development came probably to the middle - the 2 nd half of this age though this process started apparently even at the turn of the 15th - 16th centuries. In the times of Vasiliy the Third (1505-1533) the arrangement of the kremlin territory was evidently proceeded more energetically but the fire of 1537 demolished a significant part of the kremlin might cause cardinal changes in its building. As a result the author during his preparation for reconstruction choose the period of the end of 1530 -es - the turn of the 1560-es-1570-es for in December of 1569 Tver was suffered from oprichniks of Ivan the Terrible.

Keywords: Tver kremlin, building of the main street, cathedral complex, Prince's Yard and Archbishop's Yard.

У каждого города есть своя главная улица. Где-то её формирование пришлось на Новое и даже на советское время, но в европейской части России основные магистрали многих городов берут своё начало в средневековье. Не является исключением в этом отношении и Тверь. Правда, относительно зримо представление о её главной улице можно составить лишь с XVII столетия, когда, базируясь на своеобразно понимаемой реальности, застройка и градостроительная структура русского города находит отражение в работах иконописцев, а также иностранных путешественников. Петровская эпоха усилила документальное начало при изображении планировки позднесредневекового города, но в массе своей фиксация градостроительной структуры была избавлена от инструментальной съёмки, поскольку отечественные картографы первой четверти XVIII века, как правило, предпочитали ориентироваться на иконописную традицию [9, с. 68]. 
Однако на фоне этого несовершенства судить о планировке XVI столетия по изобразительным источникам того времени вообще практически невозможно. Архитектурная «реальность» в русской живописи XVI века всегда идёт рука об руку с условностью. И в житийных иконах, и в миниатюрах Лицевого летописного свода второй половины XVI века присутствует «наглядность изображения - и одновременно "сплавленность" образа, обобщённость целого» [8, с. 177], которые сложно использовать при реконструкции застройки и планиграфии древнерусского города XVI века. Тем не менее потребность в визуализации утраченных образов насыщенного тектоническими сдвигами в истории России XVI столетия остаётся и заставляет искать иные источники, которые позволили бы пусть схематически, но всё же воссоздать архитектурные «картинки» прошлого. И в этом деле определённую помощь может оказать археология, поэтому, увязывая полученные в процессе раскопок результаты с иным документальным материалом, есть возможность попытаться представить, как выглядела главная улица Тверского кремля в XVI веке.

Выбор XVI столетия в качестве основы для реконструкции архитектурного облика основной магистрали кремля представляется нам оправданным по той простой причине, что это, по всей видимости, было время наивысшего расцвета столицы некогда независимого Тверского княжества. Хотя в рамках данного столетия пик развития досмутной Твери пришёлся, скорее всего, на середину - вторую половину XVI века. Допускаю, что начало этому процессу было положено ещё на рубеже XV-XVI веков, но некоторая внутренняя неустроенность,

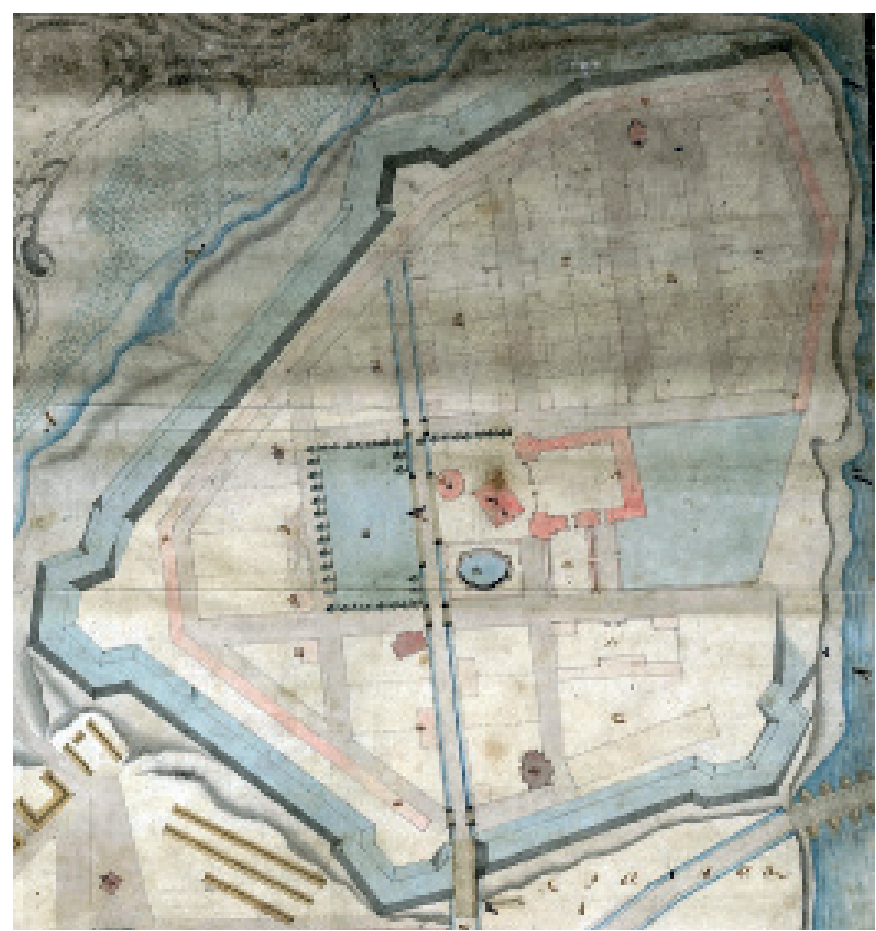

Рис. 1. Тверской кремль на «прожектированном» плане 1767 года (источник: РГИА. Ф. 1293. On. 168. Д. 8) обусловленная недавним (1485) присоединением к Москве, в определённой мере могла сдерживать градостроительное и архитектурное совершенствование Твери. Ситуация, вероятно, стала меняться во времена Василия III (1505-1533), но пожар 1537 года, уничтоживший значительную часть кремля ${ }^{1}$, мог привести к кардинальным переменам в его застройке, о чём недвусмысленно свидетельствует Максим Грек, видевший, как огонь уничтожил «многие священные храмы и дворы». И он же отметил, что «тщанием епископа Акакия все обновися лучше прежняго» [15, с. 59-60]. В итоге есть основание при подготовке вышеупомянутой реконструкции ориентироваться на период, нижней границей которого служит конец 1530-х годов. Верхнюю же можно не выводить за пределы рубежа 60-х - 70-х годов XVI века, поскольку в декабре 1569 года Тверь была разорена опричниками Ивана Грозного [13, с. 48-49].

Обозначив целью данной работы реконструкцию главной улицы Тверского кремля на середину - второю половину XVI столетия, следует отметить, что если в XVII и даже во второй половине XVIII века основная магистраль кремля, по всей видимости, сохраняла трассировку, сложившуюся в более раннее время (вероятно, даже ранее XVI века), то в середине - второй половине 1760-х годов её расположение было скорректировано градостроителями екатерининского времени. В результате «ломающаяся» где-то в районе Соборной площади улица превратилась в прямолинейную магистраль (рис. 1)2. И если её западный край оказался достаточно

${ }^{1}$ ПСРЛ. Т. 6. СПб, 1853. С. 303.

РГИА. Ф. 1293. 0п. 168. Д. 8. 1767 г.

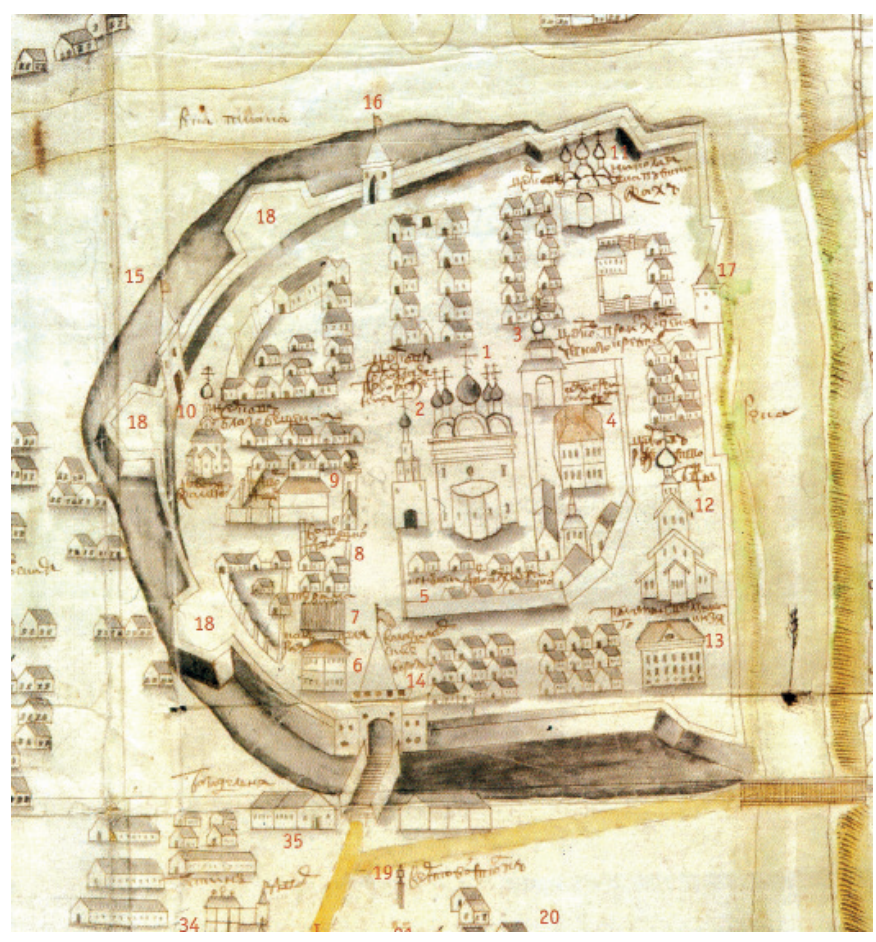

Рис. 2. И. Ярцев. Тверской кремль на рисованном плане Твери первой четверти XVIII века (источник: РГВИА. Ф. 349. On. 39. Д. 724): 14-Владимирские ворота; 16-Тьмацкие ворота 
близок появившимся в средневековье и существовавшим ещё в петровское время Тьмацким воротам кремля (рис. 2)3, то восточный значительно отклонился к югу от Владимирской башни - главного въезда в крепость со стороны Загородского посада [12, с. 134-140]. Следовательно, на реконструкции трасса основной кремлёвской улицы даётся в средневековом «ломающемся» варианте (рис. 3, 4) - так, как она могла бы выглядеть в XVI столетии. Вполне возможно, что в этот период также как и XVII веке4, эта улица называлась «Большой дорогой» или «Большой улицей».

Отсутствие каменных оборонительных сооружений в составе Тверской крепости вплоть до 1670-х годов позволяет нам изображать обе въездные башни деревянными. Более крупными были, надо полагать, Владимирские ворота. От них

${ }^{3}$ РГВИА. Ф. 349. Оп. 39. Д. 724. Первая четверть XVIII в.

${ }^{4}$ РГАДА. Ф. 1209. 0п. 1. Д. 470. 1685-1686 гг. Л. 71. бревенчатая мостовая вела к Соборной площади, центральной постройкой которой являлся кафедральный Спасо-Преображенский собор.

Соборный комплекс кремля наделён непростой историей, но благодаря проведённым в 1990-е и в 2010-е годы раскопкам у нас сегодня есть основание утверждать, что выстроенный в конце XIII века и обновлённый неоднократно храм находился в стороне от того собора, что был возведён в конце XVII столетия. На месте созданного в 1689-1696 годы нового кафедрала археологи обнаружили жилую постройку, выстроенную, возможно, в конце XIV - начале XV века [11, с. 245-247; 255-273]. Это было деревянное на белокаменном цоколе сооружение, вероятно, погибшее в пожар 1537 года, а затем, по всей видимости, возведённое в том же материале (дереве), но с учётом архитектурных стандартов, принятых в первой половине - середине XVI века (см. рис. 4, № 6).

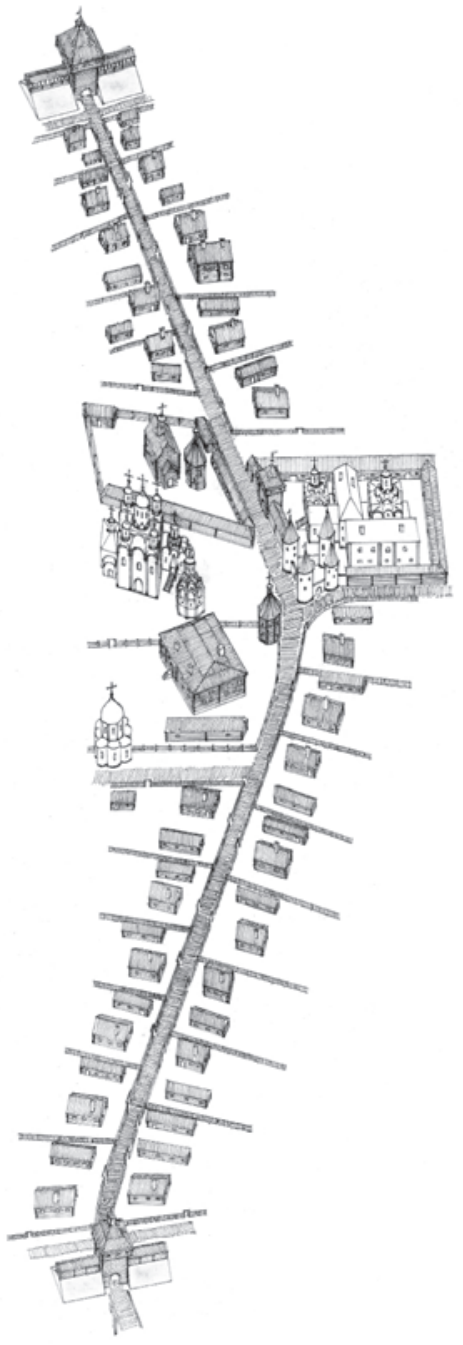

Рис. 3. Главная улица Тверского кремля в XVI веке. Вид с запада сверху. Аксонометрия. Схематическая реконструкция А.М. Салимова

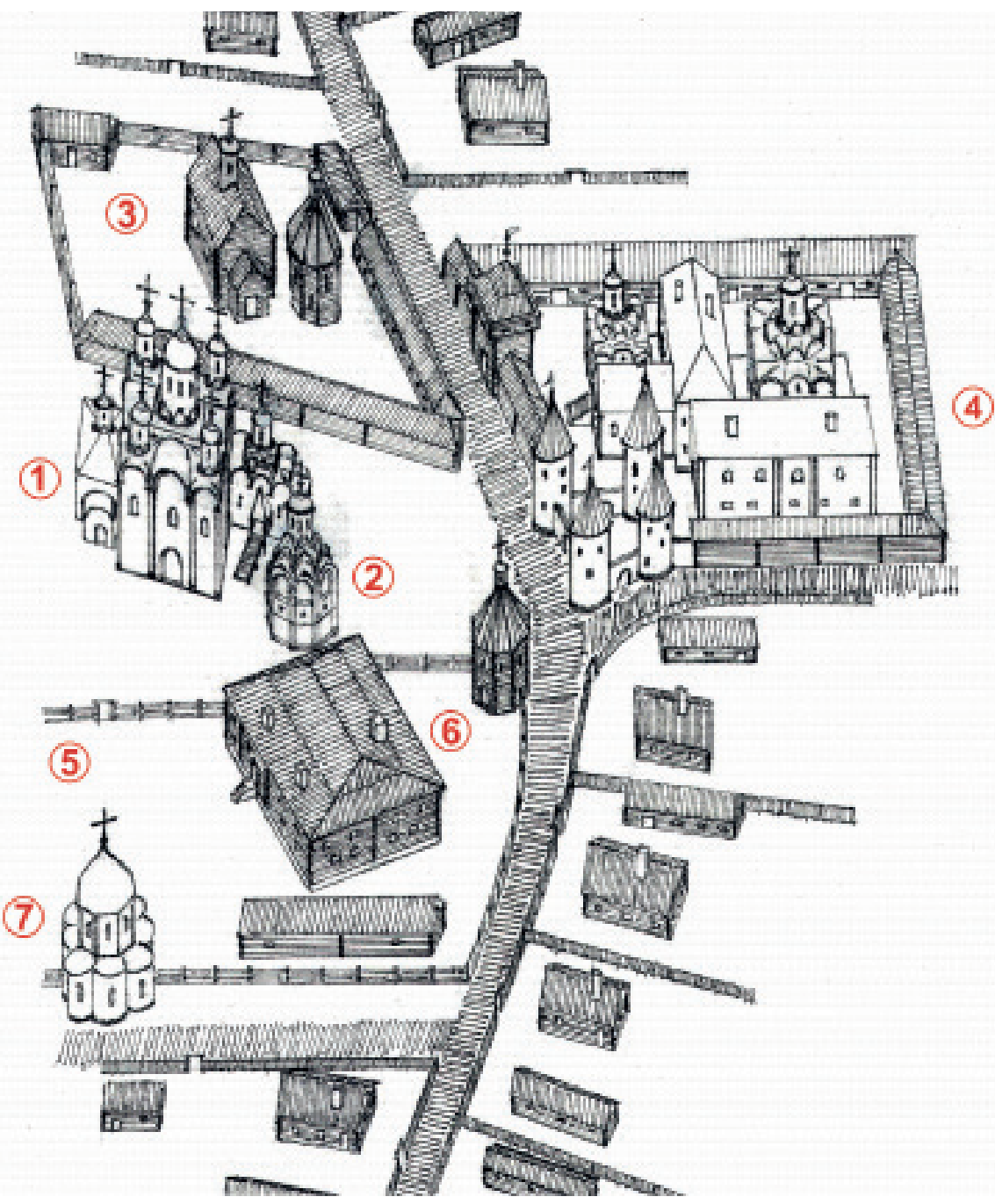

Pис. 4. Центральная часть главной улицы Тверского кремля в XVI веке. Вид с запада сверху. Аксонометрия Схематическая реконструкция А.М. Салимова: 1 - Cnaсо-Преображенский собор; 2 - колокольня; 3 - Афанасьевский монастырь; 4 - Княжий двор; 5 - Владычный двор; 6 - основные палаты тверского архиерея; 7 - церковь Иоанна Милостивого 
Если же говорить о выстроенном в 1285-1290 годы Спасо-Преображенском соборе, то опираясь на данные многолетних археологических исследований в центре Тверского кремля и сведения письменных источников, его можно разместить к северо-востоку от владычных палат (см. рис. 4, № 1). Надо полагать, что в XVI веке, принимая во внимание широкое использование при строительстве новых (или обновлении отдельных старых) кафедральных соборов, а также при создании ряда основополагающих монастырских храмов, у тверского Спаса могли видоизменить венчающую часть. Не исключено, что его изначально одноглавый основной объём уже в начале - первой трети XVI века заменили «освящённым пятиглавием», вошедшим в практику древнерусской архитектурно-строительной деятельности после возведения в 1475-1479 годы Успенского собора Московского кремля. Допускаю также, что замена венчающей композиции у тверского кафедрала могла произойти во второй половине - конце 1530-х годов, когда Спас обновляли после пожара 1537 года [11, с. 72-87].

За пределы XVI века нельзя, вероятно, выводить и реконструкцию выстроенной в 1407 году ${ }^{5}$ соборной колокольни (см. рис. 4, № 2). Косвенно эта версия подтверждается тем, что в

${ }^{5}$ ПСРЛ. Т. 11. М., 1965. С. 198.

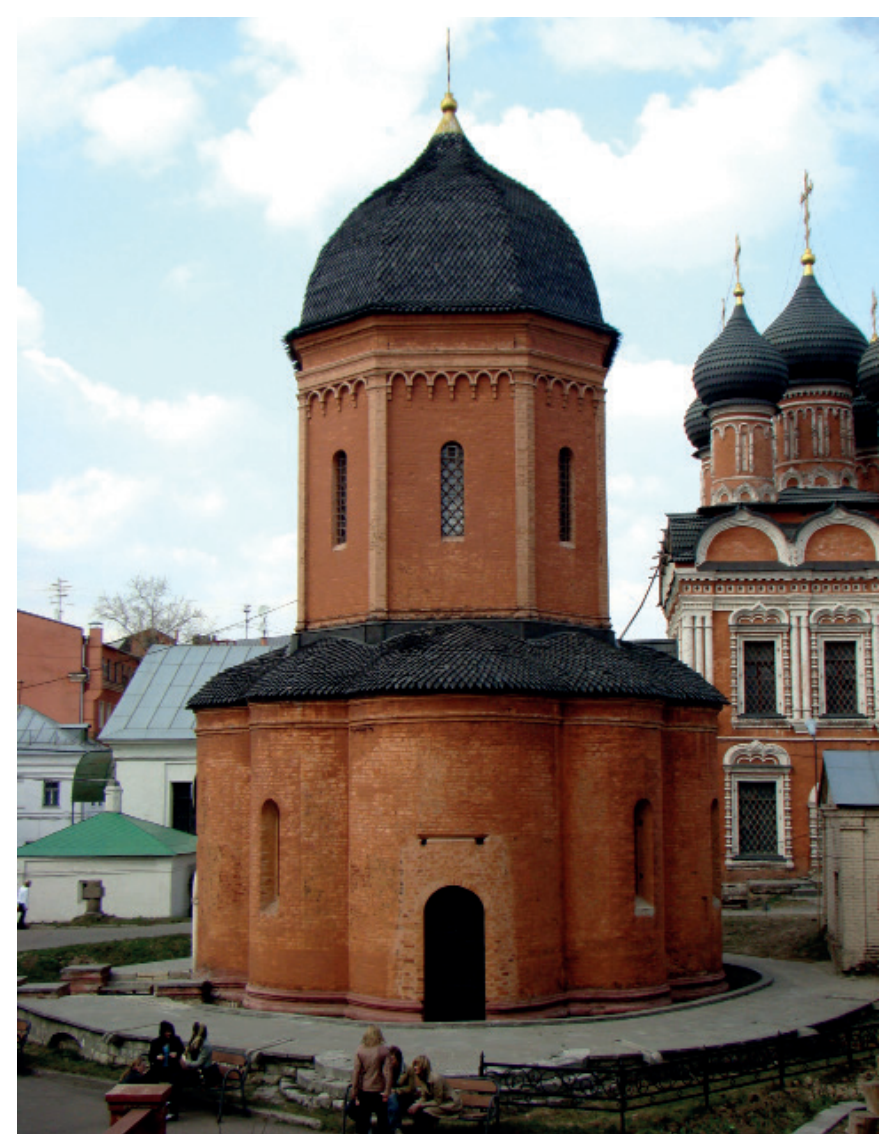

Рис. 5. Москва. Высокопетровский монастырь. Собор святителя Петра, митрополита Киевского и всея Руси. Первая четверть XVI века Фото А.М. Салимова
1636 году на этой колокольне собирались ремонтировать часы [15, с. 80]. Их вряд ли бы установили после Смуты начала XVII века, поэтому есть основание относить появление часов на колокольне Спасо-Преображенского храма к XVI столетию [11, с. 97, 115]. Заметим, что при их монтаже могли не ограничиться небольшим внедрением в стеновую кладку здания. Возможно, для устройства часов надстроили дополнительный ярус [11, с. 97, 115], хотя нельзя исключать и того, что к середине - второй половине XVI века постройка начала XV века во многом сохранила первоначальные архитектурные формы. Учитывая же характер расположения ключевых зданий центральной части Тверского кремля, колокольню Спасо-Преображенского собора логично разместить к югу или даже к юго-западу от кафедрального храма. Правда, следует уточнить, что основополагающие постройки соборного комплекса ещё предстоит найти археологам.

Неотъемлемой частью Владычного двора в XVI веке стала церковь Иоанна Милостивого (см. рис. 4, № 7), хотя это сооружение могло быть выстроено тверским князем Иваном Михайловичем ещё в первой четверти XV века в качестве отдельно стоящего здания. Во второй половине XVII века оно было перестроено с сохранением первоначального нижнего яруса [10, с. 380-394; 12, с. 218-220], который, как свидетельствует чертёж шведского инженера Эрика Пальмквиста (1674), был лепестковым в плане [7, л. 14]. Этот факт позволяет рассматривать данную постройку в контексте весьма оригинальных сооружений, аналоги которым можно найти в западнорусском зодчестве XIII-XIV веков, а также среди московских храмов начала XVI века, созданных под руководством итальянских зодчих [10, с. 380-394; 12 , с. 218-220]. При реконструкции предпочтение было отдано второй версии, поскольку после пожара 1537 года эта постройка в результате ремонта могла приобрести тот облик, который, к примеру, характерен для церкви Петра Митрополита в московском Высокопетровском монастыре (рис. 5).

Не менее, а, может быть, даже более значительным, чем комплекс Владычной резиденции был, вероятно, ансамбль Княжьего двора, располагавшийся к югу Спасо-Преображенского собора. Сведения о местоположении и площади этого двора присутствуют в писцовой книге Твери 1685-1686 годов ${ }^{6}$, которая и стала основополагающим источником в деле локализации данного комплекса (см. рис. 4, № 4), хотя справедливости ради следует отметить, что это не единственный документ XVII века, где были зафиксированы «двор и полаты Великих Князей» тверских ${ }^{7}$. Правда, после Смуты это - запустевшая территория, с 1620-х годов ставшая каменоломней при ремонте и строительстве ряда тверских церквей. Известно, к примеру, что в 20-x - 30-х годах XVII века благодаря строительному материалу, полученному «из рушенных храмов и из палат» Княжьего двора в Тверском кремле, шло

${ }^{6}$ РГАДА. Ф. 1209. 0п. 1. Д. 470. 1685-1686 гг. Л. 71.

7 Там же. 
обновление кафедрального Спасо-Преображенского собора и строительство Успенской церкви Жёлтикова монастыря [4,

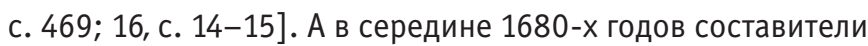
писцовой книги отмечают на месте Княжьего двора практически пустое место, «что бывал двор и полаты Великих Князей»8, Таким образом, уже во второй половине XVII века (а, может быть, и ранее) княжеский архитектурный ансамбль перестал существовать.

Создание княжеской резиденции в Тверском кремле произошло не позже середины XIII века. Первые каменные постройки появились здесь, по всей видимости, ещё в XIV столетии, а в первой половине - середине XV века этот комплекс украсился двумя каменными храмами: Борисоглебским (1435-1438) и Архангельским (1452-1455) [2, с. 294, 328 ${ }^{9}$, Эти данные позволяли предполагать, что к началу XVI века это уже был грандиозный ансамбль, в состав которого входили каменные храмы и каменные же палаты, но дальше этого обобщённого представления о Княжьем дворе дело не шло. Ситуацию коренным образом изменили раскопки, которые были проведены в районе данного комплекса в 1998 году. Они позволили выявить фрагменты нескольких башен

${ }^{8}$ РГАДА. Ф. 1209. 0п. 1. Д. 470. 1685-1686 гг. Л. 71.

${ }^{9}$ ПСРЛ. Т. 15. СПб., 1863. Стб. 490-491, 495.

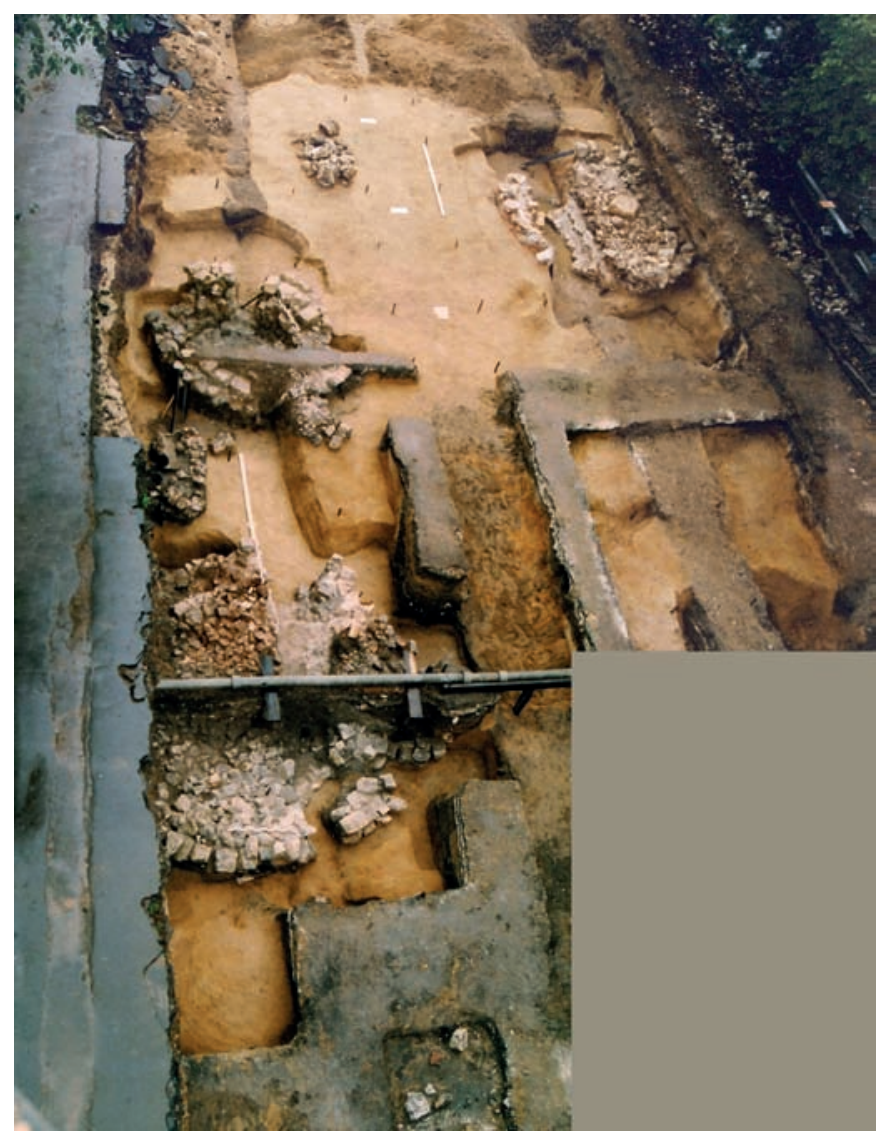

Рис. 6. Остатки каменных башен, раскрытых при раскопках в процессе реконструкции Советской улицы в городе Твери. Вид с востока сверху. Фото А.Н. Хохлова. 1998 год (рис. 6), которые, по всей видимости, являлись составными элементами небольшого (четырёхбашенного - ?) за́мка, служившего, вероятно, казной в структуре Княжьего двора [10, с. 225-258]. Замок, очевидно, находился в северо-западной части княжеской резиденции, в непосредственной близости от культовых, жилых и хозяйственных построек многосоставного ансамбля. А поскольку Борисоглебскую церковь тверской князь Борис Александрович возвёл «среди своего двора», а Михаило-Архангельскую - «на сенех» [2, с. 294, 328], то на реконструкции (см. 4, № 4) первая (справа) показана более крупным сооружением. Обилие же каменной жилой застройки на реконструкции объясняется тем, что после пожара 1537 года жилой комплекс Княжьего двора мог получить развитие и к середине XVI века включать несколько каменных зданий. Вряд ли он был таким же масштабным, как великокняжеская резиденция в Московском кремле или даже княжеская в Угличском [5, с. 58-90], тем не менее в процессе формирования здесь, вероятно, не ограничились только одной «палатой». К тому же в источнике 1636 года, зафиксировавшем разрушающийся тверской княжеский комплекс, говорится не о «палате», а о «палатах» [4, с. 469; 16, с. 14-15]. Дополнительным аргументом в пользу не одного, а нескольких каменных сооружений на территории Княжьего двора в XVI веке является факт наличия в середине - второй половине XVI века как минимум двух каменных жилых построек в составе расположенного севернее Владычного двора [12, с. 308-310] ${ }^{10}$.

К числу ансамблей центральной части Тверского кремля относился и Афанасьевский монастырь, впервые упомянутый в летописи под 1297 год ${ }^{11}$. Создание этой обители, местоположение которой писцовые книги XVI века локализуют «у Спаса за олтарем» $[3$, с. 158, 195, 220, 290], позволяют разместить её в непосредственной близости от алтарной части Спасо-Преображенского собора.

Посвящение соборного храма, расположенного рядом со Спасом Афанасьевского монастыря, позволяет с уверенностью полагать, что оно связано с монашеским именем первого тверского князя Ярослава Ярославича (1230-1271) [6, с. 144] и, следовательно, основание обители можно отнести к 60-м - началу 70-х годов XIII века. В свою очередь, отмеченная источником конца XIII века постройка церкви «святого Афонасия» является, по всей видимости, свидетельством возобновления соборного храма Афанасьевского монастыря после пожара 1295 года12. Вероятно, это было деревянное здание [6, с. 144]. Если в конце XIV века оно было цело, то именно в этом храме в 1399 году перед кончиной принял постриг тверской князь Михаил Александрович ${ }^{13}$.

\footnotetext{
${ }^{10}$ На реконструкции они не показаны, поскольку находились к северу от церкви Иоанна Милостивого, то есть достаточно далеко от главной улицы кремля.

${ }^{11}$ ПСРЛ. Т. 10. СПб, 1885. С. 171.

${ }^{12}$ Там же.

${ }^{13}$ ПСРЛ. Т. 15. Петроград, 1922. Стб. 173-174.
} 
Расположенная «у Спаса за олтарем» деревянная церковь «Афанасий великий» сгорела во время Смуты начала XVII века [14, с. 13]. Между 1616 и 1626 годами она была возобновлена, и при составлении в 1626 году очередной городской описи был отмечен «храм Афанасия и Кирилла древен ниской» [1, с. 27]. К концу XVII столетия собор Афанасьевского монастыря представлял собой «гораздо ветхое» сооружение ${ }^{14}$, которое, по всей видимости, разобрали в ближайшие после переписи начала XVIII века годы - на городском плане 1710-х годов (см. рис. 2) Афанасьевская церковь отсутствует. Таким образом, на реконструкции все постройки Афанасьевского монастыря предстают в качестве деревянных сооружений (см. рис. 4, № 3).

Что касается усадебной застройки, располагавшейся вдоль главной улицы Тверского кремля, то в силу практически полного отсутствия каких-либо документальных данных (в том числе и археологических) на этот предмет, она показана предельно обобщённо, хотя и с учётом имеющихся знаний о хронологически близких архитектурных формах.

\section{Лuтература}

1. Выпись из Тверских писцовых книг Потапа Нарбекова и подъячаго Богдана Фадеева. 1626 год. - Тверь : Тверская ученая архивная комиссия, 1901. - 147 с.

2. Инока Фомы Слово похвальное // Памятники литературы древней Руси. Вторая половина XV века. - М. : Художественная литература, 1982. - 688 с.

3. Писцовые книги Московского государства / Под ред. Н.В. Калачова. - СПб : издание Императорскаго русскаго географическаго общества, 1877.

4. Успенский Александр. Столбцы бывшего Архива 0ружейной палаты / А. Успенский. Вып. 2.- М. : Общ. арх. М-ва имп. двора, 1913.

5. Булкин, Вал. А. Строительства Андрея Большого в Угличском кремле по материалам архитектурно-археологических исследований 1985-1989 гг. / Вал. А. Булкин, А.М. Салимов // Seminarium Bulkinianum IV : К 80-летию со дня рождения Валентина Александровича Булкина: Сб. статей. - СПб : Каламос, 2017. - 360 с.

6. Воронин, Н.Н. Зодчество Северо-Восточной Руси XII-XV веков : В 2-х томах. Т. 2 // Н.Н. Воронин. - М. : Издательство Академии наук СССР, 1962.

7. Заметки о России, сделанные Эриком Пальмквистом в 1674 году. - М. : Ломоносовъ, 2012 - 344 с.

8. Подобедова, О.И. Московская школа живописи при Иване IV : работы в Московском Кремле 40-x-70-х годов XVI в. / О.И. Подобедова. - М. : Наука, 1972. - 197 с.

9. Салимов, А.М. План города Старицы первой четверти XVIII века / А.М. Салимов, М.А. Салимова // Архитектурное наследство.- 2010. - Вып. 53. - С. 64-72.

${ }^{14}$ РГАДА. Ф. 237. 0п. 1. Д. 46. 1701-1702 гг. Л. 94 об.
10. Салимов, А.М. Средневековое зодчество Твери и прилежащих земель. XII-XVI века : В 2-х томах. / А.М. Салимов. - Тверь : ГАСК, 2015. - Т. 1. - 592 с. ISBN 978-5-85291-109-4.

11. Салимов, А.М. Тверской Спасо-Преображенский собор. XIII - начало XXI века / А.М. Салимов. - Тверь : Салимовы и Ко, 2019. - 376 с. ISBN 978-5-6043203-0-3.

12. Салимов, А.М. Архитектура Твери XVII века / А.М. Салимов. - Тверь : Салимовы и Ко, 2020. - 544 с. ISBN 9785-6043203-1-0.

13. Сорина, Х.Д. Роль Верхневолжья в образовании и развитии Русского централизованного государства в XV-XVII вв. : Учеб. пособие / Х.Д. Сорина. - Калинин : Калиниский университет - 83 с.

14. Сторожев, В.Н. Дозорная книга Твери 1616 года / Сторожев В.Н. - Тверь, 1890. - 39 с.

15. Чередеев, К. Биографии тверских иерархов / К. Чередеев. - Тверь, 1859.

16. Шереметев, С.Д. Жёлтиковский монастырь в Твери / С.Д. Шереметев. - М. : типо-лит. Н.А. Куманина, 1899. - 47 с.

\section{References}

1. Vypis' iz Tverskikh pistsovykh knig Potapa Narbekova i pod"yachago Bogdana Fadeeva. 1626 god [Extract from the Tver scribal books of Potap Narbekov and the subordinate Bogdan Fadeev. 1626 year]. - Tver', Tver Scientific Archive Commission Publ., 1901, 147 p. (In Russ.)

2. Inoka Fomy Slovo pokhval'noe [Monk Thomas the word is praiseworthy]. In: Pamyatniki literatury drevnei Rusi. Vtoraya polovina XV veka [Monuments ofliterature of ancient Russia. Second half of the 15th century]. Moscow, Khudozhestvennaya literature Publ., 1982, 688 p. (In Russ.)

3. Kalachov N.V. (ed.). Pistsovye knigi Moskovskogo gosudarstva [Scripts of the Moscow State]. St. Petersburg, Edition of the Imperial Russian Geographical Society, 1877. (In Russ.)

4. Uspensky Alexander Stolbtsy byvshego Arkhiva Oruzheinoi palaty [Columns of the former Armory Archive], Iss. 2. Moscow, Obshch. arkh. M-va imp. Dvora Publ., 1913. (In Russ.)

5. Bulkin Val. A., Salimov A.M. Stroitel'stva Andreya Bol'shogo v Uglichskom kremle po materialam arkhitekturno-arkheologicheskikh issledovanii 1985-1989 gg. [Construction of Andrey Bolshoy in the Uglich Kremlin based on materials from architectural and archaeological research 1985-1989]. In: Seminarium Bulkinianum IV: K80-letiyu so dnya rozhdeniya Valentina Aleksandrovicha Bulkina [Seminarium Bulkinianum IV: On the occasion of the 80th birthday of Valentin Aleksandrovich Bulkin], collection of articles. St. Petersburg, Kalamos Publ., 2017, 360 p. (In Russ.)

6. Voronin N.N. Zodchestvo Severo-Vostochnoi Rusi XIIXV vekov [The architecture of North-Eastern Russia XII-XV centuries], in 2 volumes. Vol. II. Moscow, USSR Academy of Sciences Publishing House, 1962. (In Russ.)

7. Zametki o Rossii, sdelannye Erikom Pal'mkvistom v 1674 godu [Notes about Russia made by Eric Palmquist in 1674]. Moscow, Lomonosov Publ., 2012, 344 p. (In Russ.) 
8. Podobedova 0.I. Moskovskaya shkola zhivopisi pri Ivane IV : raboty v Moskov-skom Kremle 40-kh-70-kh godov XVI v. [Moscow school of painting under Ivan IV: works in the Moscow Kremlin in the $40 \mathrm{~s}-70$ s of the 16 th century]. Moscow, Nauka Publ., 1972, 197 p. (In Russ.)

9. Salimov A.M., Salimova M.A. Plan goroda Staritsy pervoi chetverti XVIII veka [Plan of the town of Staritsa of the first quarter of the 18th century]. In: Arkhitekturnoe nasledstvo [Architectural heritage], 2010, Iss. 53, pp. 64-72. (In Russ., abstr. in Engl. )

10. Salimov A.M. Srednevekovoe zodchestvo Tveri i prilezhashchikh zemel'. XII-XVI veka [Medieval architecture of Tver and adjacentlands. XII-XVI centuries], in 2 volumes. Tver', GASK Publ., 2015, Vol. 1, 592 p. ISBN 978-5-85291-109-4. (In Russ.)

11. Salimov A.M. Tverskoi Spaso-Preobrazhenskii sobor. XIII - nachalo XXI veka [Tver Spaso-Preobrazhensky Cathedral. XIII - early XXI century]. Tver', Salimovs and Co Publ., 2019, 376 p. ISBN 978-5-6043203-0-3. (In Russ.)
12. Salimov A.M. Arkhitektura Tveri XVII veka [The architecture of Tver in the 17th century]. Tver', Salimovs and Co Publ., 2020, 544 p. ISBN 978-5-6043203-1-0. (In Russ.)

13. Sorina Kh.D. Rol' Verkhnevolzh'ya v obrazovanii i razvitii Russkogo tsentralizovannogo gosudarstva v XV - XVII vv. [The role of the Upper Volga region in the formation and development of the Russian centralized state in the 15th - 17th centuries]. Kalinin, Kalinin University Publ., 1978, 83 p. (In Russ.)

14. Storozhev V.N. Dozornaya kniga Tveri 1616 goda [The patrol book of Tver in 1616]. Tver', published by the Tver Scientific Archive Commission6 1890, 39 p. (In Russ.)

15. Cheredeev K. Biografii tverskikh ierarkhov [Biographies of the Tver hierarchs]. Tver', Printing house of the provincial government, 1859. (In Russ.)

16. Sheremetev S.D. Zheltikovskii monastyr' v Tveri [Zheltikovsky monastery in Tver ]. Moscow, tipo-lit. N.A. Kumanina Publ., 1899, 47 p. (In Russ.)

Салимов Алексей Маратович (Тверь). Доктор искусствоведения, член-корреспондент РААСН. Главный научный сотрудник Научно-исследовательского института теории и истории архитектуры и градостроительства (филиал ФГБУ «ЦНИИП Минстроя России») (111024, Москва, ул. Душинская, 9. НИИТИАГ). Эл.почта: sampochta@mail.ru.

Salimov Aleksey M. (Tver). Doctor of Arts, Corresponding Member of RAACS. Chief Researcher at the Scientific Research Institute of Theory and History of Architecture and Urban Planning (branch of TsNIIP of the Ministry of Construction of Russia) (9 Dushinskaya st., Moscow, 111024. NIITIAG).E-mail: sampochta@mail.ru. 